NASA/TM-2008-215217

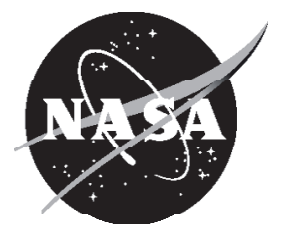

\title{
K-Band TWTA for the NASA Lunar Reconnaissance Orbiter
}

Dale A. Force, Rainee N. Simons, and Todd T. Peterson

Glenn Research Center, Cleveland, Ohio

Adan Rodriguez-Arroy and Jirasak Visalsawat

Goddard Space Flight Center, Greenbelt, Maryland

Paul C. Spitsen, William L. Menninger, Neal R. Robbins, Daniel R. Dibb, and Phillip C. Todd L-3 Communications Electron Technologies, Inc., Torrance, California 


\section{NASA STI Program . . . in Profile}

Since its founding, NASA has been dedicated to the advancement of aeronautics and space science. The NASA Scientific and Technical Information (STI) program plays a key part in helping NASA maintain this important role.

The NASA STI Program operates under the auspices of the Agency Chief Information Officer. It collects, organizes, provides for archiving, and disseminates NASA's STI. The NASA STI program provides access to the NASA Aeronautics and Space Database and its public interface, the NASA Technical Reports Server, thus providing one of the largest collections of aeronautical and space science STI in the world. Results are published in both non-NASA channels and by NASA in the NASA STI Report Series, which includes the following report types:

- TECHNICAL PUBLICATION. Reports of completed research or a major significant phase of research that present the results of NASA programs and include extensive data or theoretical analysis. Includes compilations of significant scientific and technical data and information deemed to be of continuing reference value. NASA counterpart of peer-reviewed formal professional papers but has less stringent limitations on manuscript length and extent of graphic presentations.

- TECHNICAL MEMORANDUM. Scientific and technical findings that are preliminary or of specialized interest, e.g., quick release reports, working papers, and bibliographies that contain minimal annotation. Does not contain extensive analysis.

- CONTRACTOR REPORT. Scientific and technical findings by NASA-sponsored contractors and grantees.

- CONFERENCE PUBLICATION. Collected papers from scientific and technical conferences, symposia, seminars, or other meetings sponsored or cosponsored by NASA.

- SPECIAL PUBLICATION. Scientific, technical, or historical information from NASA programs, projects, and missions, often concerned with subjects having substantial public interest.

- TECHNICAL TRANSLATION. Englishlanguage translations of foreign scientific and technical material pertinent to NASA's mission.

Specialized services also include creating custom thesauri, building customized databases, organizing and publishing research results.

For more information about the NASA STI program, see the following:

- Access the NASA STI program home page at http://www.sti.nasa.gov

- E-mail your question via the Internet to help@ sti.nasa.gov

- Fax your question to the NASA STI Help Desk at 301-621-0134

- Telephone the NASA STI Help Desk at 301-621-0390

- Write to: NASA Center for AeroSpace Information (CASI) 7115 Standard Drive Hanover, MD 21076-1320 
NASA/TM-2008-215217

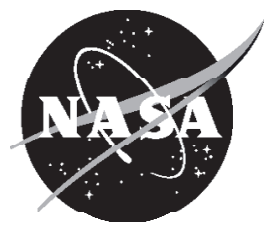

\section{K-Band TWTA for the NASA Lunar Reconnaissance Orbiter}

Dale A. Force, Rainee N. Simons, and Todd T. Peterson

Glenn Research Center, Cleveland, Ohio

Adan Rodriguez-Arroy and Jirasak Visalsawat

Goddard Space Flight Center, Greenbelt, Maryland

Paul C. Spitsen, William L. Menninger, Neal R. Robbins, Daniel R. Dibb, and Phillip C. Todd L-3 Communications Electron Technologies, Inc., Torrance, California

Prepared for the

Ninth International Vacuum Electronics Conference (IVEC 2008)

sponsored by the IEEE Electronic Devices Society

Monterey, California, April 22-24, 2008

National Aeronautics and

Space Administration

Glenn Research Center

Cleveland, Ohio 44135 
This report is a preprint of a paper intended for presentation at a conference.

Because changes may be made before formal publication, this preprint is made available with the understanding that it will not be cited or reproduced without the permission of the author.

Level of Review: This material has been technically reviewed by technical management.

Available from

NASA Center for Aerospace Information 7115 Standard Drive

Hanover, MD 21076-1320
National Technical Information Service 5285 Port Royal Road Springfield, VA 22161

Available electronically at http://gltrs.grc.nasa.gov 


\title{
K-Band TWTA for the NASA Lunar Reconnaissance Orbiter
}

\author{
Dale A. Force, Rainee N. Simons, and Todd T. Peterson \\ National Aeronautics and Space Administration \\ Glenn Research Center \\ Cleveland, Ohio 44135 \\ Adán Rodriguez-Arroy and Jirasak Visalsawat \\ National Aeronautics and Space Administration \\ Goddard Space Flight Center \\ Greenbelt, Maryland 20771 \\ Paul C. Spitsen, William L. Menninger, Neal R. Robbins, Daniel R. Dibb, and Phillip C. Todd \\ L-3 Communications Electron Technologies, Inc. \\ Torrance, CA 90509
}

\begin{abstract}
This paper presents the K-Band traveling wave tube amplifier (TWTA) developed for the Lunar Reconnaissance Orbiter and discusses the new capabilities it provides.
\end{abstract}

\section{Introduction}

The Lunar Reconnaissance Orbiter (LRO) is the first mission in NASA's Vision for Space Exploration, a plan to return to the moon and then to travel to Mars and beyond. LRO will launch in late 2008 with the objective to finding safe landing sites, locate potential resources, characterize the radiation environment, and demonstrate new technology.

The spacecraft will be placed in low polar orbit $(50 \mathrm{~km})$ for a 1-yr mission under NASA's Exploration Systems Mission Directorate. LRO will return global data, such as day-night temperature maps, a global geodetic grid, high-resolution color imaging and the moon's UV albedo. However, there is particular emphasis on the polar regions of the moon where continuous access to solar illumination may be possible and the prospect of water in the permanently shadowed regions at the poles may exist. After one year, the Orbiter will transition to a science phase under NASA's Science Mission Directorate (ref. 1). The Orbiter Program Office is located at NASA Goddard Spaceflight Center.

The K-Band data link transmits at $25.65 \mathrm{GHz}$ with lefthanded circular polarization, with rate $1 / 2, \mathrm{~K}=7$ convolutional and RS coding. The transmission rate is $228.7 \mathrm{Msps}$ for normal operations (100 Mbps before coding) with contingency rates of 114.3 Msps (50 Mbps) and 57.2 Msps (25 Mbps). LRO uses a $75 \mathrm{~cm}$ combined S-band/K-Band high-gain antenna for the K-Band link, transmitting to an $18 \mathrm{~m}$ antenna at White Sands, New Mexico. Since the orbiter needs $40 \mathrm{~W}$ of RF power to provide adequate margin on the link, a TWTA was needed.
The LRO TWTA contract (ref. 2) is managed by the NASA Glenn Research Center as a continuation of the $32 \mathrm{GHz}$ high power TWT program with L-3 Communications, Electron Technologies, Inc. (ETI), which produced a $180 \mathrm{~W}$ TWT (ref. 3). Two TWTAs were produced under the contract, a Flight Model and a Protoflight Model, which also functions as a spare.

\section{TWTA Design}

By basing the design of the LRO TWT on the $180 \mathrm{~W}$ TWT, we were able to provide a very robust TWT for the LRO mission very rapidly. The chief changes needed were to redesign the input and output couplers to connect to WR-34 instead of WR-28 waveguide, and to modify the helix design for the lower power and frequency. The TWTs are shown in figure 1.

The LRO TWT is a helix TWT with a four stage depressed collector, samarium cobalt periodic permanent magnetic focusing, and a tungsten/osmium cathode.

The Electronic Power Conditioner (EPC) design is based on the L-3 Communications, ETI standard $2300 \mathrm{Hx}$ series, with the necessary modifications to meet the LRO specifications. The most significant change was to the input filter and magnetics to reduce the conducted emissions of the EPC. The modifications reduced the conducted emissions by more that $20 \mathrm{~dB}$, although the EPC is still short of the stringent MILSTD-461C. The L-3 Communications ETI designation of the TWTA is Model $9835 \mathrm{H}$.

The following tables compare the NASA specifications for the TWTA (table I) with the actual performance of the Flight TWTA (table II) and Protoflight TWTA (table III).

Except for the conducted emission, the Flight TWTA meets the NASA specifications. The Flight TWTA was delivered for integration into the Lunar Reconnaissance Orbiter communications subsystem in January 2008. The Protoflight TWTA meets the NASA specifications except for the conducted emissions and for the worst case DC power consumption. The Protoflight TWTA was delivered in April 2008. 


\section{Future Missions}

A third TWT was built under this program (SN 203). The third TWT is being considered for the Communication Navigation and Networking Reconfigurable Testbed (CoNNeCT). The LRO TWTA design also serves as the baseline for the Lunar Communications Terminal (LCT).

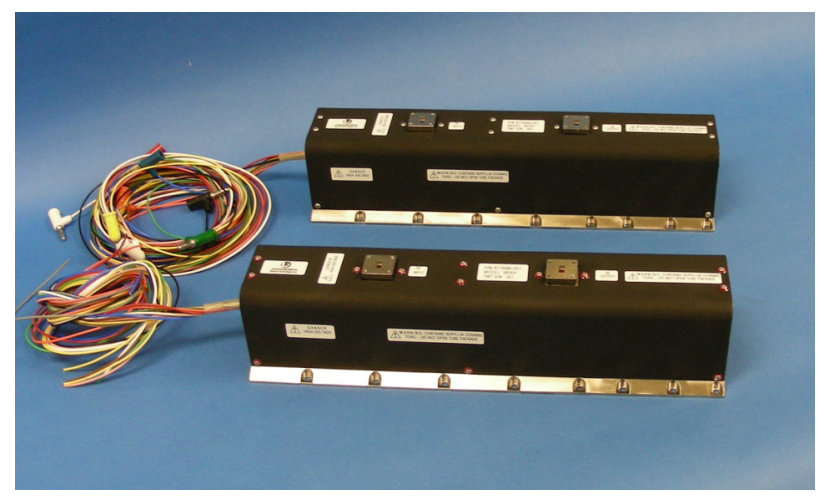

Figure 1.-Flight and protoflight TWTs.

TABLE I.-TWTA K-BAND TWTA SPECIFICATIONS

\begin{tabular}{|l|l|}
\hline \multicolumn{1}{|c|}{ Parameter } & \multicolumn{1}{|c|}{ NASA Specifications } \\
\hline Frequency band & 25.5 to $25.8 \mathrm{GHz}$ \\
\hline Output power (CW) & $40 \mathrm{~W}$ min. \\
\hline Saturated gain & $46 \mathrm{~dB}$ min. \\
\hline Saturated gain flatness & $0.5 \mathrm{~dB}$ max. \\
\hline AM-to-PM & $4.5 \%$ dB max. \\
\hline VSWR & $2.0: 1$ max. \\
\hline TWT efficiency & 44 percent min. \\
\hline Mass & 3.5 kg max. \\
\hline DC power & 104 W max. \\
\hline Overall efficiency & 38.5 percent min. \\
\hline Operating/mission life & $14 / 26$ mos. \\
\hline Environment & Lunar orbit \\
\hline Input/output ports & WR-34 \\
\hline EMI/EMC specification & MIL-STD-461C \\
\hline
\end{tabular}

TABLE II.-TWTA K-BAND TWTA SN 201 (FLIGHT MODEL) PERFORMANCE

\begin{tabular}{|c|c|}
\hline Parameter & Performance \\
\hline Frequency band & 25.5 to $25.8 \mathrm{GHz}$ \\
\hline Output power (CW) & $41.6 \mathrm{~W}$ min. \\
\hline Saturated gain & $48.93 \mathrm{~dB}$ min. \\
\hline Saturated gain flatness & $0.3 \mathrm{~dB}$ \\
\hline AM-to-PM & $3.3^{\circ} / \mathrm{dB} \max$. \\
\hline VSWR & 1.7:1 max. \\
\hline TWT efficiency & 49.5 percent $\min$. \\
\hline Mass & $2.95 \mathrm{~kg}$ \\
\hline DC power & $94.6 \mathrm{~W}$ max. \\
\hline Overall efficiency & 44.0 percent $\min$. \\
\hline
\end{tabular}

TABLE III.-TWTA K-BAND TWTA SN 202 (PROTOFLIGHT MODEL) PERFORMANCE

\begin{tabular}{|l|l|}
\hline \multicolumn{1}{|c|}{ Parameter } & \multicolumn{1}{c|}{ Performance } \\
\hline Frequency band & 25.5 to $25.8 \mathrm{GHz}$ \\
\hline Output power $(\mathrm{CW})$ & $41.0 \mathrm{~W}$ min. \\
\hline Saturated gain & $47.93 \mathrm{~dB}$ min. \\
\hline Saturated gain flatness & $0.1 \mathrm{~dB}$ \\
\hline AM-to-PM & $2.6^{\circ} / \mathrm{dB}$ max. \\
\hline VSWR & $1.81: 1$ max. \\
\hline TWT efficiency & 44.6 percent min. \\
\hline Mass & $2.95 \mathrm{~kg}$ \\
\hline DC power & $107.8 \mathrm{~W}$ max. \\
\hline Overall efficiency & 38.0 percent min. \\
\hline
\end{tabular}

1. http://lunar.gsfc.nasa.gov/mission.html

2. NASA Glenn Research Center Contract Number NNC04CB13C.

3. W. Menninger, N. Robbins, D. Dibb, and D. Lewis, "Power Flexible Ka-band Traveling Wave Tube Amplifiers of Up to 250-W RF for Space Communications," IEEE Trans. Electron Devices, vol. 54, no. 2, pp. 181-187, Feb. 2007. 


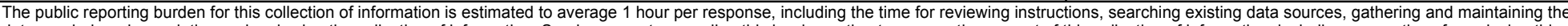

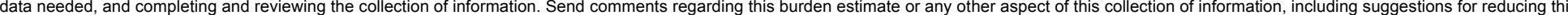

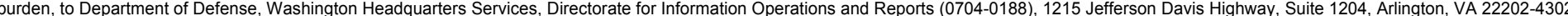

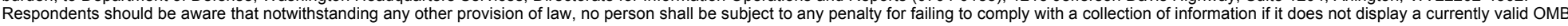
control number.

PLEASE DO NOT RETURN YOUR FORM TO THE ABOVE ADDRESS.
1. REPORT DATE (DD-MM-YYYY)
2. REPORT TYPE
3. DATES COVERED (From - To)

01-04-2008

Technical Memorandum

\section{TITLE AND SUBTITLE}

K-Band TWTA for the NASA Lunar Reconnaissance Orbiter

5a. CONTRACT NUMBER

5b. GRANT NUMBER

5c. PROGRAM ELEMENT NUMBER

\section{AUTHOR(S)}

Force, Dale, A.; Simons, Rainee, N.; Peterson, Todd, T.; Rodriguez-Arroy, Adan; Visalsawat, Jirasak; Spitsen, Paul, C.; Menninger, William, L.; Robbins, Neal, R.; Dibb, Daniel, R.; Todd,

Phillip, C.

\section{5d. PROJECT NUMBER}

5e. TASK NUMBER

5f. WORK UNIT NUMBER

WBS 342556.06.01.10.01.02

\section{PERFORMING ORGANIZATION NAME(S) AND ADDRESS(ES)}

National Aeronautics and Space Administration

8. PERFORMING ORGANIZATION REPORT NUMBER

John H. Glenn Research Center at Lewis Field

E-16506

Cleveland, Ohio 44135-3191

\section{SPONSORING/MONITORING AGENCY NAME(S) AND ADDRESS(ES)}

National Aeronautics and Space Administration

Washington, DC 20546-0001

\section{SPONSORING/MONITORS ACRONYM(S) \\ NASA \\ 11. SPONSORING/MONITORING REPORT NUMBER \\ NASA/TM-2008-215217}

\section{DISTRIBUTION/AVAILABILITY STATEMENT}

Unclassified-Unlimited

Subject Category: 17

Available electronically at http://gltrs.grc.nasa.gov

This publication is available from the NASA Center for AeroSpace Information, 301-621-0390

\section{SUPPLEMENTARY NOTES}

\section{ABSTRACT}

This paper presents the K-Band traveling wave tube amplifier (TWTA) developed for the Lunar Reconnaissance Orbiter and discusses the new capabilities it provides.

\section{SUBJECT TERMS}

Telecommunications; Transmitters; Deep space network; Space communication; Satellite communications; Microwave transmission; Microwave amplifiers; Microwave tubes; Power amplifiers; Power conditioning; Power efficiency; Traveling wave tubes

\begin{tabular}{|c|c|c|c|c|c|}
\hline \multicolumn{3}{|c|}{ 16. SECURITY CLASSIFICATION OF: } & \multirow{2}{*}{$\begin{array}{l}\text { 17. LIMITATION OF } \\
\text { ABSTRACT } \\
\text { UU }\end{array}$} & \multirow{2}{*}{$\begin{array}{l}\text { 18. NUMBER } \\
\text { OF } \\
\text { PAGES } \\
8\end{array}$} & \multirow{2}{*}{$\begin{array}{l}\text { 19a. NAME OF RESPONSIBLE PERSON } \\
\text { STI Help Desk (email:help@ sti.nasa.gov) } \\
\text { 19b. TELEPHONE NUMBER (include area code) } \\
\text { 301-621-0390 }\end{array}$} \\
\hline $\begin{array}{l}\text { a. REPORT } \\
\text { U }\end{array}$ & $\begin{array}{l}\text { b. ABSTRACT } \\
\text { U }\end{array}$ & $\begin{array}{l}\text { c. THIS } \\
\text { PAGE } \\
\text { U }\end{array}$ & & & \\
\hline
\end{tabular}



